\title{
UJI HIPOTESIS PADA HASIL PEMANFAATAN PEMETAAN SMA (STUDI KASUS KAB. KARANGANYAR)
}

\author{
Mukhamad Richo Mafazan, Sumarsono1), Nurcahyani Dewi Retnowati²) \\ 1Teknik Informatika Universitas Islam Negeri Sunan Kalijaga Yogyakarta \\ 2Jurusan Teknik Informatika Sekolah Tinggi Teknologi Adisutjipto Yogyakarta \\ informatika@stta.ac.id
}

\begin{abstract}
The lack of information in the area Karanganyar especially the schools are the usual information accessible online. In the era of information technology, as now, it should be information about the school, information about the schools that are managed and published through the Internet. Some existing sites and information support the schools in the area tend to be static. The information displayed tended outdated information and even out-of-date, not updated in quite a long period of time. Then create a mapping application Senior High School Case Study Karangnyar District. With the application of Mapping Mash-up Senior High School in Karanganyar, the user can see the schools without having to come to school to see school information desired. To make the application Mapping Mash-up Senior High School In Karanganyar JSON format which utilizes lighter and then made accessible to the web service. Results of experiments performed as expected ie when the user opens a web service can simply select senior high school or vocational high school category and public or private category so people can see the information on each school were selected.
\end{abstract}

Keywords: Rest, Json, Mash-up

\section{Pendahuluan}

Minimnya informasi di daerah Kabupaten Karanganyar terutama informasi letak sekolah yang biasa diakses online. Dalam era teknologi informasi seperti sekarang ini, sudah seharusnya informasi mengenai, letak sekolah, informasi tentang sekolah yang dikelola dan dipublikasikan melalui internet. Beberapa situs yang sudah ada dan mendukung informasi letak sekolah di daerah cenderung masih bersifat statis. Informasi yang ditampilkan cenderung informasi yang sudah lama dan bahkan out-of-date, tidak diperbaharui dalam kurun waktu yang cukup lama.

Sehingga dilakukan penelitian mengembangkan web service sistem pemetaan Sekolah Menengah Atas di Kabupaten Karanganyar berbasis web yang mampu dikembangkan ke arah yang bersifat dinamis dan up-to-date, tidak terkecuali pada proses penyajian berita dan review (ulasan) mengenai lokasi atau daerah tersebut yang memang menjadi fokus dari tugas akhir ini.

\section{Metodologi}

Pada penelitian yang dilakukan oleh Deny Arief Kurniawan (2012) dengan memvisualisasikan peta administrasi Kecamatan Selat dan peta Pendidikan Dasar Kecamatan Selat. Sistem Informasi Geografis tersebut mampu menyampaikan informasi-informasi SD dan SMP di Kecamatan Selat, mampu melakukan pencarian sekolah menurut jalan dan 
menurut kelurahan, mampu membantu admin Dinas Pendidikan Kabupaten Kapuas untuk mengubah atau memperbaharui data-data sekolah, dan dapat membantu Dinas Pendidikan Kabupaten Kapuas mengambil keputusan untuk memperbaharui bangunan atau menambah ruang kelas sekolah serta menambah tenaga pengajar.

Pada penelitian yang dilakukan oleh Andy Pramono (2012), kebutuhan akan ketersediaan informasi yang cukup akurat sangat dibutuhkan dalam segala bentuk kegiatan atau usaha, baik itu dalam lingkup pemerintahan maupun usaha. Demikian pula dalam hal ketersediaan informasi data non akademik sekolah sangat diperlukan bagi Dinas Pendidikan dan Kebudayaan Kabupaten Pasuruan, yang selama ini mengalami kesulitan dalam mengambil kebijakan pengembangan pendidikan di Kabupaten Pasuruan karena kurangnya informasi non akademik sekolah. Penelitian ini menghasilkan suatu aplikasi visualisasi pemetaan sekolah Kabupaten Pasuruan yang akan menghasilkan suatu aplikasi yang mampu memberikan informasi mengenai data non akademik sekolah bagi Dinas Pendidikan Kabupaten Pasuruan yang divisualisasikan dalam bentuk pemetaan vektor 2D ini dilaksanakan dalam beberapa tahap melalui tahap pengumpulan data dan analisa, konsep perancangan aplikasi (konsep perancangan meliputi DFD, ER, Desain Interface) dan implementasi dan ujicoba.

\subsection{Diagram Konteks}

Diagram konteks (Gambar 1) dimana user dapat memilih inputan SMA/SMK sehingga menemui sebuah hasil yang dicari tersebut.

\section{Detail SMA.SMKK}

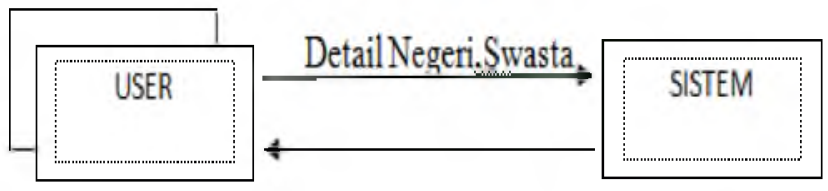

Detail hasil

Gambar 1. Diagram Konteks

\subsection{Diagram Alir Data}

DAD (Gambar 2) dari aplikasi ini berawal user mengakses sistem lalu sistem mencari data di database yang sudah di-input-kan oleh admin. 


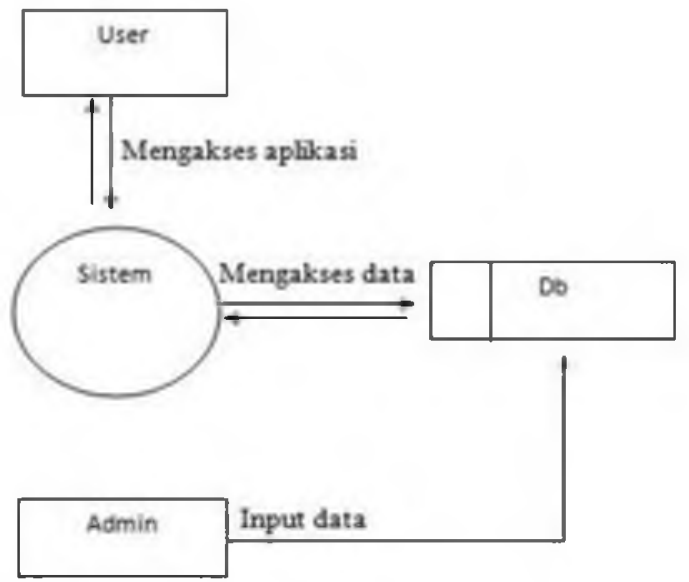

Gambar 2. DAD

\subsection{Flowchart System}

Flowchart (Gambar 3) aplikasi ini mempunyai sistem kerja berawal dari start lalu user memilih inputan lalu diproses, jika user memilih kategori sekolah SMA dan memilih kategori status swasta maka akan diproses mengambil data dari database, jika user memilih inputan kategori sekolah SMK dan kategori status swasta maka juga akan diproses mengambil data dari database lalu dari database menjadi hasil untuk menampilkan informasi di dalam aplikasi tersebut.

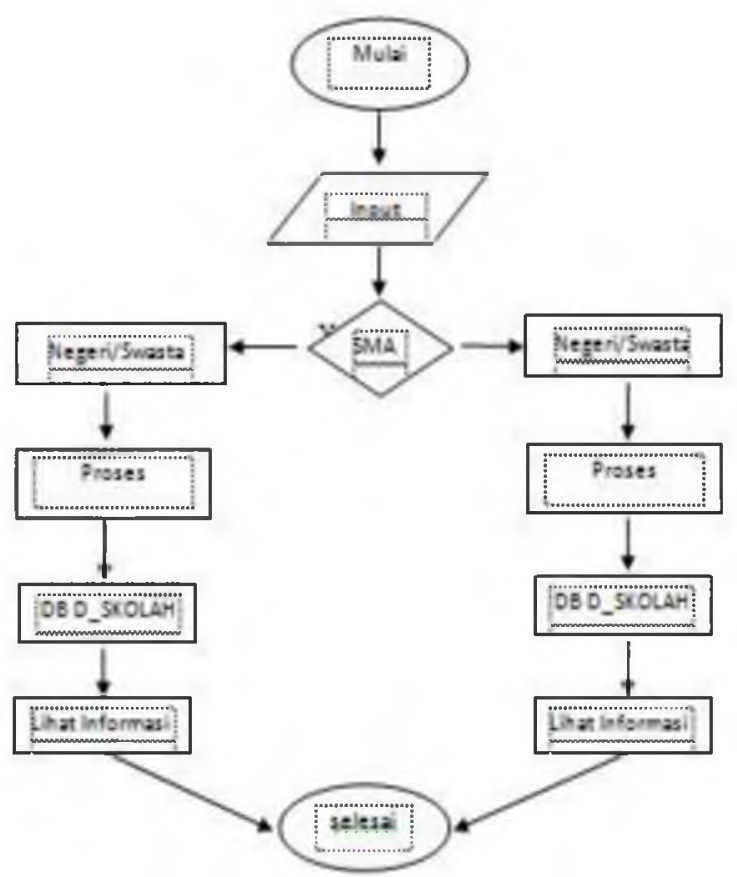

Gambar 3. Flowchart System

\section{Hasil dan Pembahasan}

Di dalam aplikasi ini terdapat database untuk menyimpan data-data sekolah yang akan diolah dan diserialisasi ke format JSON seperti yang terlihat pada Gambar 4 . 


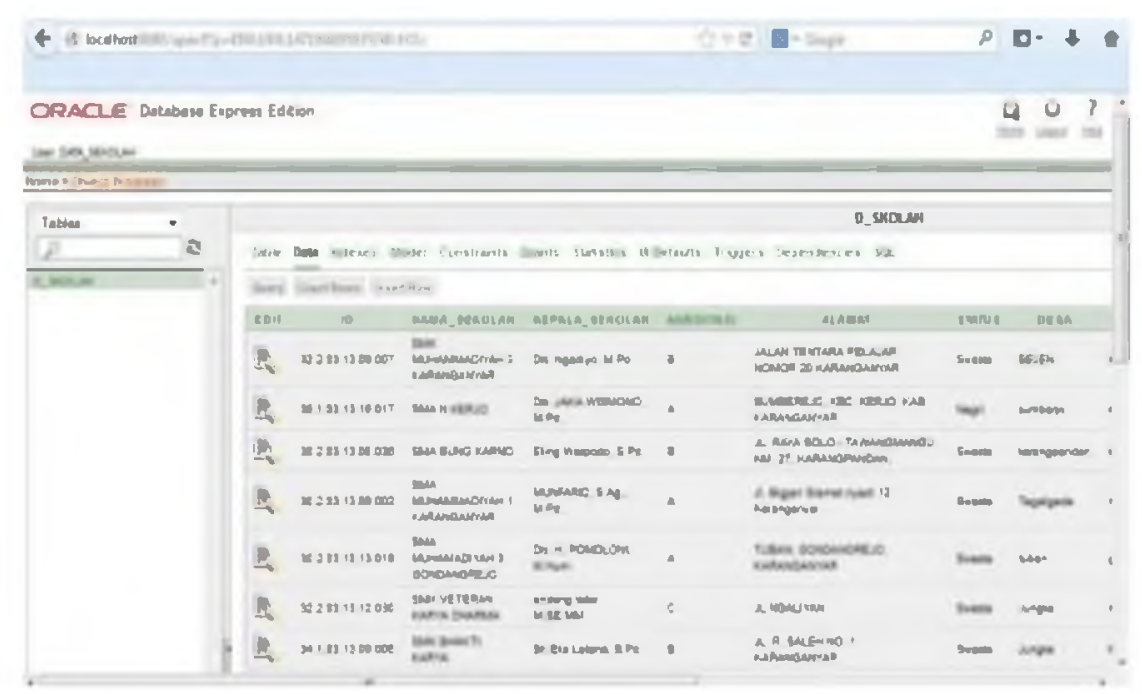

Gambar 4. Sistem Database

\subsection{Proses Serialisasi Json}

Untuk proses serialisasi, pengambilan data dari database merubah ke bentuk file format JSON dibutuhkan script untuk merubah data dari database tersebut seperti yang terlihat pada Gambar 5.

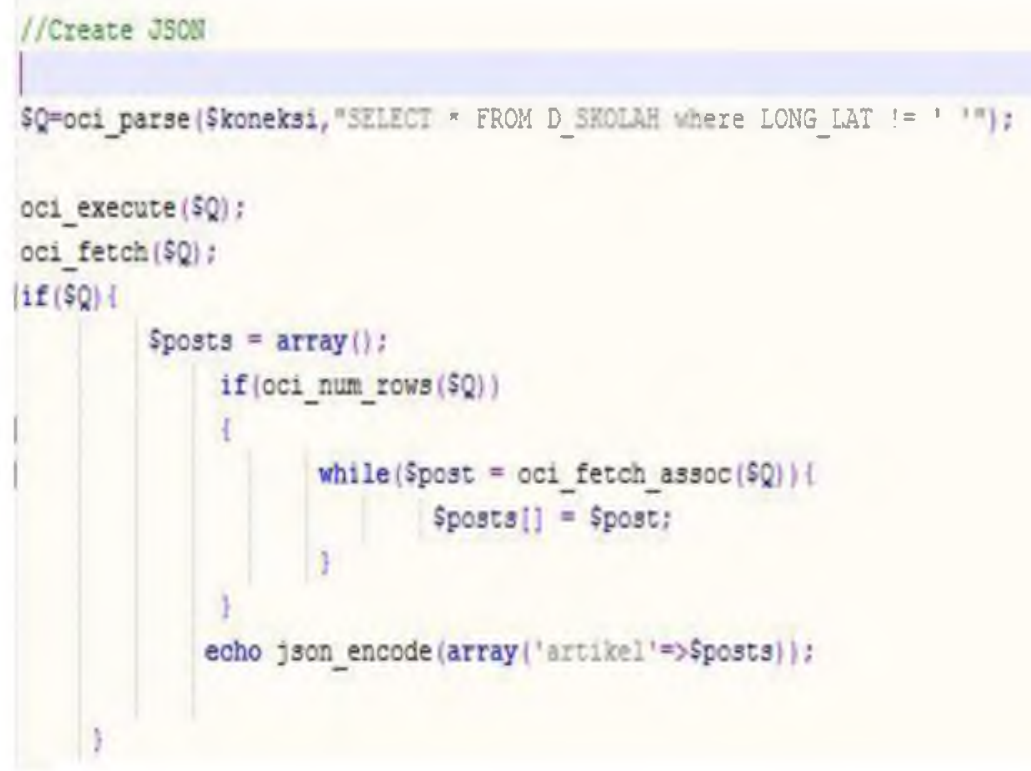

Gambar 5. Proses Serialisasi JSON

\subsection{Hasil Serialisasi Database Ke Json}

Setelah hasil dari serialisasi ke JSON berhasil dan sudah muncul data berbentuk format file JSON maka langkah selanjutnya mengambil link yang berada pada browser dan setelah itu link data JSON diakses ke langkah selanjutnya untuk diterapkan di aplikasi, seperti yang terlihat pada Gambar 6. 


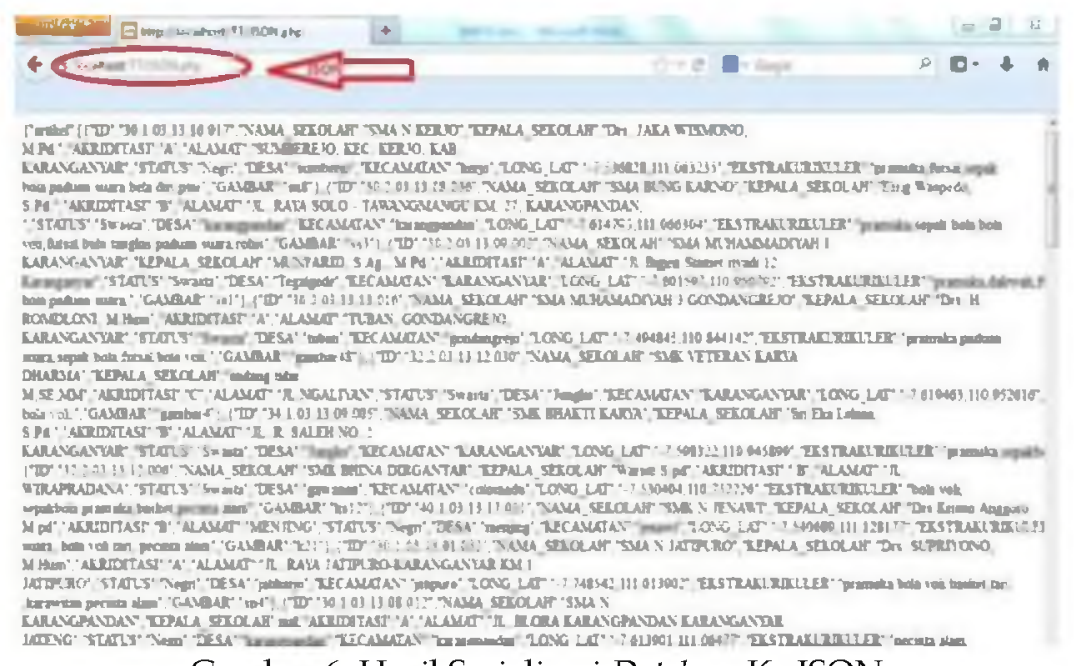

Gambar 6. Hasil Serialisasi Database Ke JSON

\subsection{Komponen Curl}

Akan tetapi sebelum mencapai hasil seperti yang terlihat pada Gambar 6 diharuskan mengaktifkan komponen curl. Karena tanpa menggunakan extension $=$ php-curl data format JSON tidak akan muncul dan untuk mengaktifkan extension php-curl silahkan buka php.ini lalu cari extension php-curl selanjutnya hapus titik koma di depan extension seperti yang terlihat pada Gambar 7 .

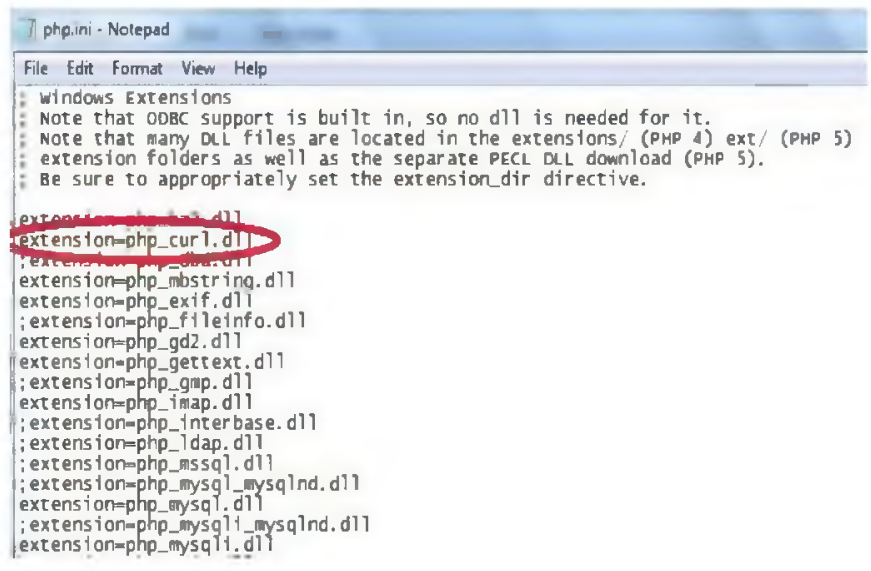

Gambar 7. Komponen Curl

\subsection{Konsum Data Json Ke Mash-Up}

Langkah selanjutnya mengkonsum data JSON ke mash-up, tinggal mengkonsum, mengambil data yang kiranya akan dieksekusi, yang ingin ditampilkan pada aplikasi mash-up pemetaan SMA di Kabupaten Karanganyar tersebut seperti yang terlihat pada Gambar 8. 


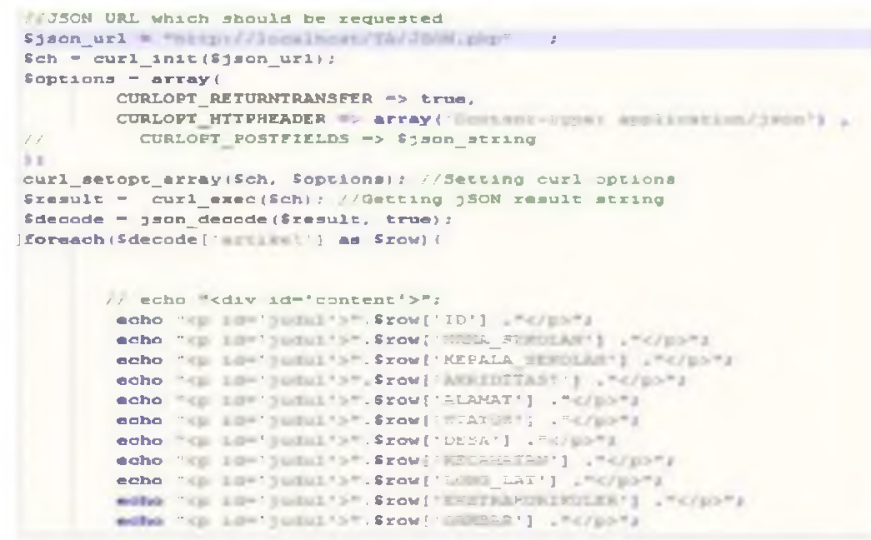

Gambar 8. Konsum Data JSON ke Mash-up

\subsection{Halaman Utama}

Halaman utama terdapat menu-menu yang mempermudah user untuk menggunakan aplikasi ini diantaranya pilihan kategori SMA, SMK, pilihan kategori Negeri, Swasta dan tombol cari untuk mencari letak-letak sekolah yang ingin dicari (Gambar 9).

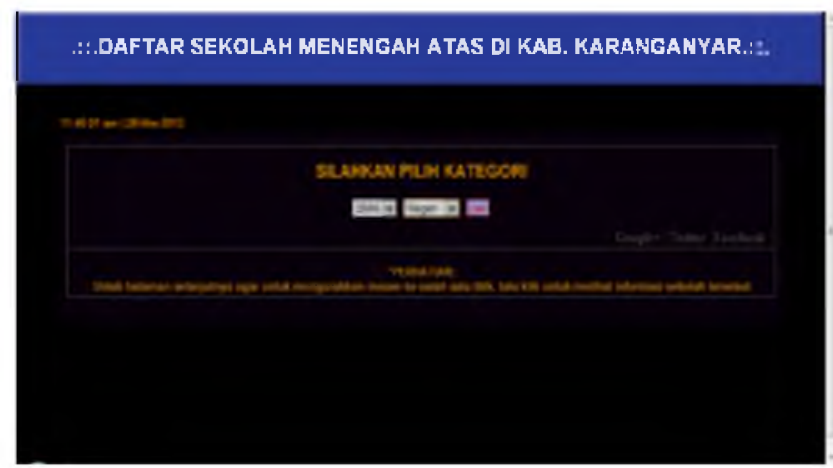

Gambar 9. Implementasi Halaman Utama

\subsection{Implementasi Halaman Map}

Di implementasi halaman map terlihat hasil setelah mengklik tombol cari pada Gambar 10 dan ada menu back untuk kembali ke halaman utama seperti yang terlihat pada Gambar 11.

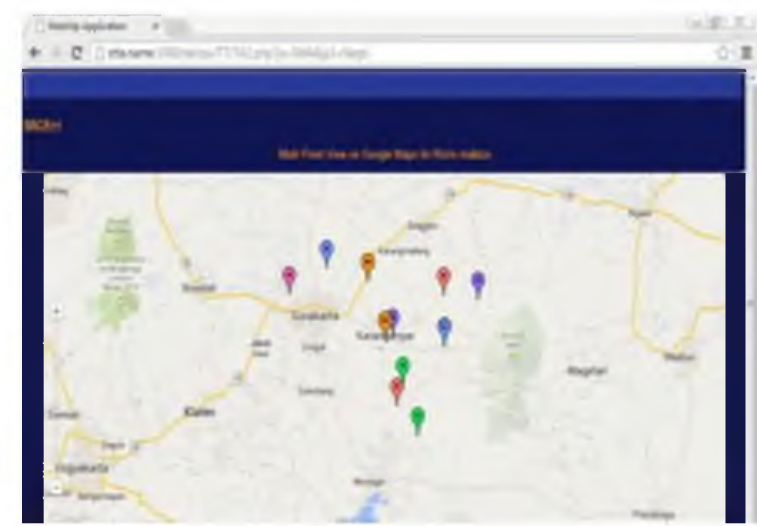

Gambar 10 Implementasi Halaman Map 
User juga bisa melihat info jelasnya pada setiap sekolah. Untuk melihat info jelasnya pada setiap sekolah maka kursor dapat diarahkan pada salah satu balon dalam map lalu klik balon tersebut dan nantinya akan muncul sebuah informasi sekolah yang diklik tersebut (Gambar 11).

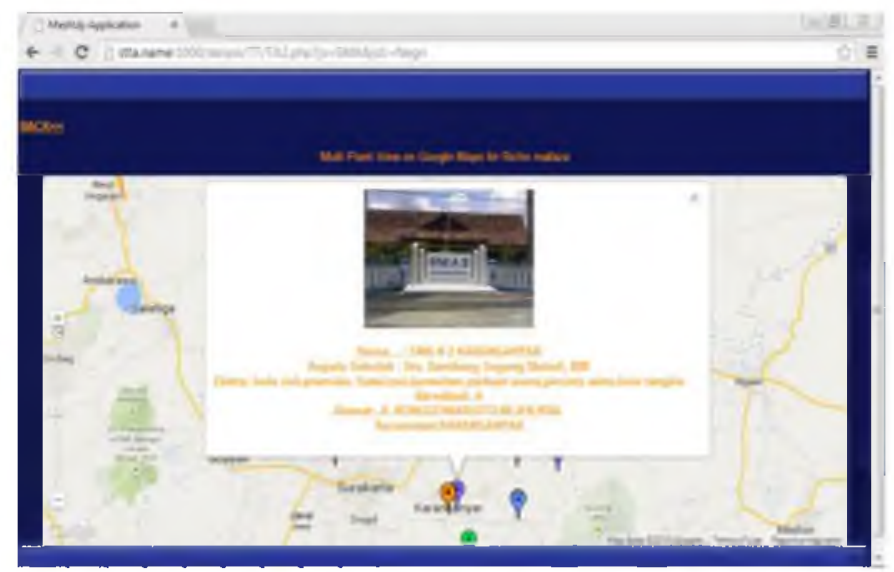

Gambar 11. Melihat Informasi Pada Sekolah

Setelah muncul hasil, ada juga menu di halaman map tersebut yaitu tombol back untuk kembali ke halaman utama.Aplikasi pemetaan SMA di Kabupaten Karanganyar ini adalah untuk melihat seberapa optimalnya kinerja sistem ini dan untuk mendapatkan bukti dalam bentuk angka per-detik.

Dalam mengakses SMA Negeri membutuhkan waktu 32,74 s dalam pengujian ini tidak memastikan waktu yang ditempuh selalu 32,74 s karena cepat dan lambatnya mengakses tergantung provider (Gambar 12).

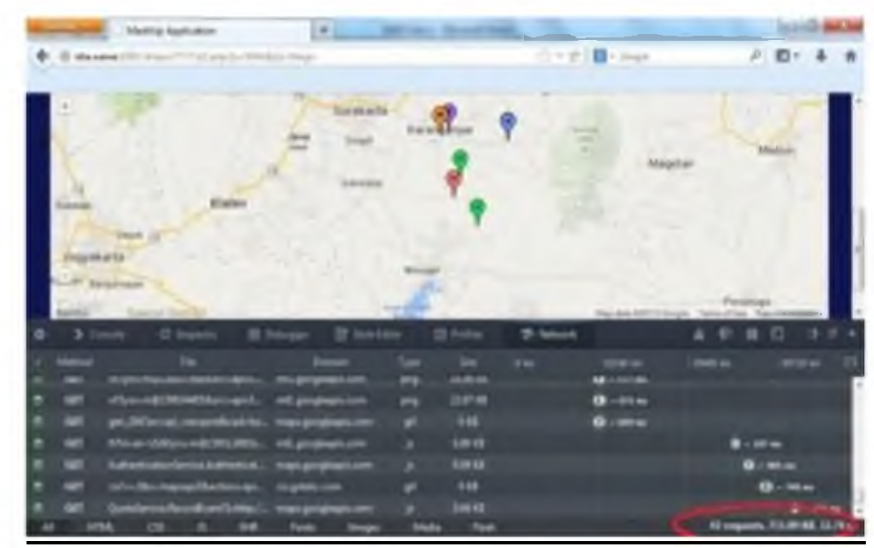

Gambar 12.Uji Pencarian SMA Negeri

Dalam mengakses SMA Swasta membutuhkan waktu 10,96 s dalam pengujian ini tidak memastikan waktu yang ditempuh selalu 10,96 s karena cepat dan lambatnya mengakses tergantung provider (Gambar 13). 


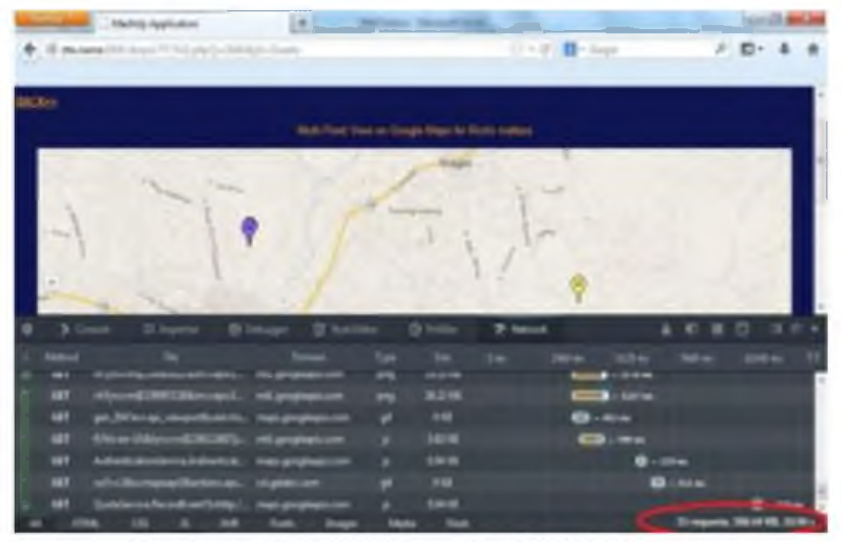

Gambar 13. Uji Pencarian SMA Swasta

\subsection{Uji Coba Fungsi Dengan Menerapkan Peralatan}

Berdasarkan uji coba menggunakan perangkat keras (Tabel 1), dalam pengujjian ini perangkat smartphone Samsung Galaxy Chat B5330 lebih cepat dengan waktu 11,07s dalam mengakses aplikasi ini di banding PC, Laptop dan hand phone biasa, tetapi dalam pengujian ini tidak selamanya smartphone Samsung Galaxy Chat B5330 selalu cepat dalam mengakses aplikasi pemetaan SMA ini karena cepat lambatnya dalam mengakses selain spesifikasi perangkat yang mempengaruhi yaitu jaringan atau provider juga mempengaruhi.

Tabel 1. Uji Coba Fungsi Dengan Menerapkan Peralatan

\begin{tabular}{|c|c|c|c|c|}
\hline No & Perangkat & Spesifikasi & Waktu Ke-1 & $\begin{array}{c}\text { Waktu Ke- } \\
2\end{array}$ \\
\hline 1 & PC & $\begin{array}{l}\text { RAM (Random Access } \\
\text { Memory) } 512 \text { Mb. } \\
\text { Harddisk berkapasitas } 2 \\
\text { Gb Layar monitor } \\
19^{\prime \prime} \text { inc }\end{array}$ & $16,57 \mathrm{~s}$ & $19,07 \mathrm{~s}$ \\
\hline 2 & $\begin{array}{l}\text { Toshiba } \\
\text { NB200 }\end{array}$ & $\begin{array}{l}\text { RAM (Random Access } \\
\text { Memory) } 512 \mathrm{Mb} \text {. } \\
\text { Harddisk berkapasitas } 2 \\
\text { Gb. Layar monitor } \\
12^{\prime \prime} \text { inc }\end{array}$ & $27,57 \mathrm{~s}$ & $24,50 \mathrm{~s}$ \\
\hline 3 & $\begin{array}{l}\text { Samsung } \\
\text { Galaxy } \\
\text { Chat } \\
\text { B5330 }\end{array}$ & $\begin{array}{l}\text { Android OS, v4.0 (Ice } \\
\text { eam Sandwich). } 118.9 \times \\
.3 \times 11.7 \mathrm{~mm}(4.68 \times 2.33 \\
.46 \text { in). } 4 \text { GB storage }\end{array}$ & $11,07 \mathrm{~s}$ & $14,77 \mathrm{~s}$ \\
\hline 4 & $\begin{array}{l}\text { Nokia } \\
6600\end{array}$ & $\begin{array}{l}\text { Symbian OS v7.0s, } \\
\text { Series } 60 \text { v2.0 UI. } 6 \mathrm{Mb} \\
\text { storage. } 113 \mathrm{cc}(4.29 \mathrm{x} \\
2.28 \times 0.94 \mathrm{in})\end{array}$ & $55,01 \mathrm{~s}$ & $51,09 \mathrm{~s}$ \\
\hline
\end{tabular}

\subsection{Uji Hipotesis}

Penelitian ini menggunakan model persamaan regresi linier berganda untuk melihat pengaruh, pencarian data, tampilan interface, validasi pencarian letak SMA studi 
kasus kabupaten Karanganyar. Dengan melakukan pengisian kuesioner dengan penilaian sangat baik, baik, cukup, kurang, sangat kurang.

Uji pembuktian dari hipotesis dengan terlebih dahulu dilakukan perhitungan nilai hasil kuesioner menjadi berapa persen untuk kategori pengisi kuesioner yang memilih sangat baik (X1), baik (X2), cukup (X3), kurang (X4), sangat kurang (X5). Pengolahan data dilakukan dengan menggunakan SPSS Version 10.00 for Windows.Hasil perhitungan parameter model regresi secara bersama-sama diperoleh pada Gambar 14.

Variables Entered Remoned

\begin{tabular}{|l|l|l|l|}
\hline $\begin{array}{l}\text { Mode } \\
1\end{array}$ & $\begin{array}{c}\text { Variables } \\
\text { Enitered }\end{array}$ & $\begin{array}{c}\text { Variables } \\
\text { Removed }\end{array}$ & Method \\
\hline 1 & $\begin{array}{l}x_{1} \times 2, \times 4, \times 3 \\
x_{1}=\end{array}$ & & Enter \\
\hline
\end{tabular}

a. All requested vasiables entered.

b. Dependent Variable: Pengujian

Gambar 14 Variable Entered/Removed

Dari Gambar 17 menunjukan variabel yang dimasukkan adalah X1, X2, X3, X4, X5, sedangkan variabel yang dikeluarkan tidak ada.

Model Summary

\begin{tabular}{|l|l|r|r|r|}
\hline $\begin{array}{l}\text { Mode } \\
1\end{array}$ & $R$ & $R$ Square & $\begin{array}{c}\text { Adjusted } R \\
\text { Square }\end{array}$ & $\begin{array}{c}\text { Std Error of } \\
\text { the Estimate }\end{array}$ \\
\hline 1 & $.677^{\circ}$ & .458 & .007 & 3.593 \\
\hline
\end{tabular}

a. Predictors: (Constant, $\times 5, X_{2}, X_{4}, X_{3}, X_{1}$

Gambar 15. Model Summary

Pada Gambar 15 angka $R$ square adalah 0,458 yaitu hasil kuadrat dari koefisien korelasi $(0,677 \times 0,677=0,458)$. Standar Error of the Estimate adalah 3,593, perhatikan pada analisis deskriptif statistik bahwa deviasi nilai rapot adalah 8,779 yang jauh lebih kecil dari standar error, oleh Karena lebih besar dari pada deviasi hasil kuesioner maka model regresi tidak bagus dalam bertindak sebagai predictor nilai rapot.

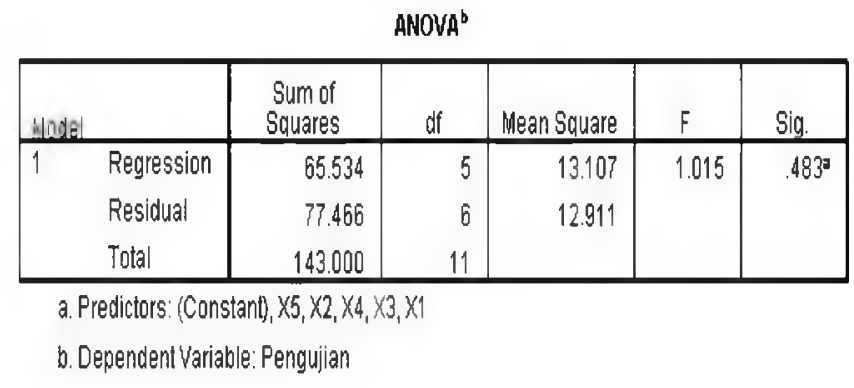

Gambar 16. Anova 
Hipotesis:

1. $\mathrm{H} 0: \mathrm{b} 1, \mathrm{~b} 2, \mathrm{~b} 3=0$ berarti tidak ada pengaruh yang signifikan dari pencarian data, tampilan interface, validasi pencarian letak SMA terhadap hasil kuesioner

2. Ha : b1, b2, b3 > 0 berarti ada pengaruh yang signifikan dari pencarian data, tampilan interface, validasi pencarian letak SMA terhadap daftar SMA studi kasus kabupaten Karanganyar

Pengambilan keputusan:

Jika F hitung $<=\mathrm{T}$ tabel atau probabilitas $>=0,05$ maka Ho diterima

Jika F hitung $>\mathrm{T}$ tabel atau probabilitas $<0,05$ maka Ho diterima

Dari Gambar 19 dapat dilihat nilai F hitung 1,015, sedangkan nilai F dapat diperoleh dengan menggunakan tabel $\mathrm{F}$ dengan derajat bebas ( $\mathrm{df}$ ) Residual (sisa) yaitu 6 sebagi df menyebut dan df Regression (pelaku) yaitu 5 sebagi df pembilang dengan tarap signifikan 0,05, sehingga diperoleh nilai $\mathrm{F}$ tabel yaitu 2,571, karena $\mathrm{F}$ hitung $(1,015)<\mathrm{F}$ tabel $(2,571)$ maka Ho diterima Berdasarkan signifikan, terlihat pada kolom sig yaitu 0,483 itu berarti probabilitas 0,483 lebih dari daripada 0,05 maka Ho diterima.

\section{Kesimpulan dan Saran}

Dari hasil perancangan dan pengujian yang dilakukan pada perangkat lunak di atas, dapat disimpulkan :

1. Pengolahan data menggunakan teknologi REST harus mengetahui skema pengolahan data REST terlebih dahulu, dengan mengolah data menggunakan REST maka lebih ringan dan sederhana karena REST mengolah data melalui link-link tidak mengolah data dari database langsung.

2. Pengolahan data JSON dan di jadikan Mash-up di sebuah web service hanya dengan mengambil link dari data JSON dan dari link JSON tersebut di olah dan diambil datanya yang kiranya di butuhkan untuk membangun Mash-up di sebuah web service.

3. Hasil uji coba yang dilakukan sesuai harapan yaitu apabila penguna membuka web service ini bisa langsung memilih kategori sekolah SMA atau SMK dan kategori Negeri atau Swasta lalu cari dan langsung bisa melihat informasi di setiap sekolah yang dipilih.

Selain kesimpulan, dari hasil pengujian perangkat lunak dapat dihimpun saran untuk pengembangan yang selanjutnya, antara lain:

1. Sebaiknya penampilan struktur akan lebih baik jika sesuai dengan hierarki yang ada agar lebih menarik.

2. Pengembangan aplikasi Mash-up Pemetaan SMA atau SMK di Kabupaten Karanganyar ini bisa menampilkan data yang lebih lengkap sehingga pengguna lebih terbantu dengan adanya web service ini.

3. Aplikasi dikembangkan dengan berbasis web mobile tidak hanya opera mobile. 


\section{Daftar Pustaka}

http:/hwww.json.org, diakses pada tanggal 15 Juni 2013.

Meza \& Zhu, 2008,Mash-uphttp://thesis.binus.ac.id/Asli/Bab2/TSA-2010-0035\%202.pdf, diakses pada tanggal 15 Juni 2013.

Nurzhan Nurseitov, Michael Paulson, Randall Reynolds, dan Clemente Izurieta, 2009. Pertukaran Data Pada JSON. http://www.cs.montana.edu/izurieta/pubs/caine2009.pdf, diakses pada tanggal 15 Mei 2013.

Kurniawan, D.S 2012.Pemetaan Pendidikan Dasar di Kecamatan Selat Berbasis Sistem Informasi Geografis. http://repository.amikom.ac.id/files/Publikasi 06.11.1226.pdf diakses pada tanggal 15 juni 2013.

Siregar, I. M., 2012.Membongkar Teknologi Web Service Jilid 2. Andi Offset. Yogyakarta.

Pramono, A., 2012, Aplikasi Visualisasi Pemetaan Sekolah Di Kabupaten Pasuruhan Jawa Tengah Visualisasi Vector 2 Dimensi Berbasis Android. Jurnal Informatika Volume 5 No. 3 Tahun 2012 . ISSN 1978-161X .Universitas Islam Negeri Maulana Malik Ibrahim. Malang. 
Mukhamad Richo Mafazan, Sumarsono, Nurcahyani Dewi Retıowati 